\title{
Introduction to special issue on sustainability and the triple bottom line within the global clothing and textiles industry
}

\author{
Kim Y. Hiller Connell ${ }^{*}$ and Joy M. Kozar ${ }^{2}$
}

*Correspondence:
kyhc@ksu.edu
${ }^{1}$ Department of Apparel,
Textiles and Interior Design,
College of Human Ecology,
Kansas State University, 321
Justin Hall, Manhattan, KS
66506, USA
Full list of author information
is available at the end of the
article

${ }^{*}$ Correspondence: kyhc@ksu.edu

Department of Appare Textiles and Interior Design, College of Human Ecology, Kansas State University, 321 66506, USA article
The clothing and textiles industry accounts for approximately $\$ 2$ trillion in global revenue. Unfortunately, the industry's penchant for natural resource consumption and generation of greenhouse gases and pollution poses remarkable threats to environmental sustainability. Additionally, human rights issues within the production of clothing and textiles, including forced and child labor, low wages, excessive hours of work with unpaid overtime, health and safety hazards, and lack of worker representation for negotiations with management also generate serious social and economic sustainability challenges. Fortunately, current industry activity responding to the sustainability challenges suggests a growing commitment to sustainable practices. So, while the environmental, social, and economic consequences associated with the clothing and textiles supply chain are serious, there are promising signs that a significant paradigm shift towards sustainability and a focus on the triple bottom line is gaining momentum.

The objectives of the special collection are to advance knowledge related to current sustainability challenges within the global clothing and textiles supply chain and seek new perspectives on initiatives within the industry to advance sustainability and the triple bottom line.

First coined by John Elkington in 1994, the triple bottom line consists of the three Ps, profit, people, and planet, by which companies should assess their bottom lines. Profit, is the traditional bottom line of finances within corporations. However, in addition to profit, triple bottom line businesses also measure their performance in terms of social (people) and environmental (planet) responsibility. Therefore, the triple bottom line is a holistic assessment of a company's economic, social, and environmental performance over time.

The triple bottom line is of primary significance as sustainable corporations have the capability of promoting larger societal value. That is, the triple bottom line business model can generate greater stakeholder value as opposed to the traditional shareholder value. Above all, the triple bottom line in the clothing and textiles supply chain is a universal method for building economic, social, and environmental resources while fostering sustainable livelihoods.

From the production of raw materials to the disposal of clothing and textile goods, responding to sustainability challenges throughout the supply chain requires a 
multi-faceted approach. Therefore, the articles included in this special issue represent a range of triple bottom line concepts. Two of the articles, Doty and Haar's examination of the utilization of sawmill byproducts as a natural dye and Michel and Lee's study of the design of clothing for the green burial movement, focus on product development/ design. In the article "Black Walnut, Osage Orange, and Eastern Redcedar Sawmill Waste as Natural Dyes," Doty and Haar explore triple bottom line impacts of utilizing sawmill waste as a natural dye. The study focuses on analyzing the impacts of potassium aluminum sulfate on the dye concentration, hue, and colorfastness to light and laundering on dyes derived from black walnut, Osage orange, and eastern redcedar while also considering economic and social aspects of the utilization of these materials as natural dyes. Next, in "Cloth(ing) for the Dead: Case Study of Three Designers' Green Burial Practices" Michel and Lee contribute to the green burial movement literature. Framed within a context of the cradle-to-cradle and eco-effectiveness design paradigm, Michel and Lee's case study of three fashion designers focuses on best practices in the design of green burial clothing. The study also explores current purchase options for green burials and ideal fabrics and fibers for green burial in terms of minimizing negative environmental after burial.

Ultimately it is the end consumer who is highly influential in advancing sustainability within the industry, and the remaining four articles within this special issue focus on understanding consumer behavior aspects of the triple bottom line within the clothing and textiles industry. Lang, Armstrong, and Liu address the role of the consumer in: "Creativity and sustainable apparel retail models: Does consumers' tendency for creative choice counter-conformity matter in sustainability?" As part of their research, the authors present several potential product-service retail models as a means for promoting sustainable apparel practices among consumers. The relationship between consumers' tendency for adopting differing sustainable retail models is analyzed, including methods such as renting and swapping clothing, clothing repair/alteration, the sale of redesigned clothing, and style consultancy services on wearing clothing in unique fashions. The findings reveal that consumers' tendency for creative choice counter-conformity has a positive influence on adopting the above mentioned sustainable retail methods. Advocating for less material-concentrated consumption by increasing product longevity, the authors report that consumers who favor creative choices in their apparel decisions are more likely to purchase unique products redesigned from old materials. Implications to the industry derived from the authors' findings underscore the possibility of adopting new retail market strategies in encouraging consumers' sustainable apparel purchasing decisions.

Diddi and Niehm focus their efforts on: "Exploring the role of values and norms towards consumers' intentions to patronize retail apparel brands engaged in corporate social responsibility (CSR)." A significant relationship between moral norms and consumers' ethical decision making is reported; the relationship between the influence of significant others on consumers' decision making processes is also found. Moral norms, subjective norms, and attitudes are all significant predictors of consumers' willingness to support apparel brands involved in CSR activities. As such, in a similar fashion to Lang et al., useful inferences exist relevant to the TBL movement within the supply chain. For example, the authors suggest that in positively impacting brand image, apparel brands 
operating in today's competitive and over-saturated retail marketplace should incorporate CSR initiatives within their marketing platforms.

In Park and Kim's study, "An empirical test of the triple bottom line of customer-centric sustainability: The case of fast fashion," the authors report a high correlation between social and environmental dimensions of the triple bottom line (TBL) model. The authors report that the TBL model is an effective tool in assessing consumers' perceptions of sustainability among fashion brands, including both fast fashion brands and sustainable fashion brands. For industry professionals, the TBL model developed and tested by the authors is practical in examining consumers' evaluations of fashion brand sustainability. Further, the authors find that environmental sustainability does not significantly predict brand outcomes (brand trust and brand loyalty) for either fast fashion brands or sustainable fashion brands. This is notable, as environmental sustainability may not be influential enough in developing consumers' strong brand relationships. Social sustainability is not a significant predictor of strong positive brand outcomes for fast fashion brands; in other words, for fast fashion retailers, consumers' do not possess positive brand outcomes related to socially responsible practices.

Finally, Ma, Gam and Banning's article, "Perceived Ease of Use and Usefulness of Sustainability Labels on Apparel Products: Application of the Technology Acceptance Model," utilizes the Technology Acceptance Model (TAM) to investigate consumers' perceptions of sustainability labels on clothing and the effectiveness of labels in determining purchase intentions. The study demonstrates that the primary variables within TAM, perceived ease of use, perceived usefulness, attitudes and purchase intentions are all associated with the use of sustainability labels on clothing by consumers (with label users scoring higher on all four variables compared to nonusers). This study supports the idea that labels can communicate the TBL practices of a business when the labels are noticed and easy to understand by consumers. Therefore, TBL clothing brands should design their labels with care, ensuring they are aesthetically pleasing, and easy to read.

\footnotetext{
Author details

${ }^{1}$ Department of Apparel, Textiles and Interior Design, College of Human Ecology, Kansas State University, 321 Justin Hall, Manhattan, KS 66506, USA. ${ }^{2}$ Department of Apparel, Textiles and Interior Design, College of Human Ecology, Kansas State University, 219 Justin Hall, Manhattan, KS 66506, USA.
}

\section{Publisher's Note}

Springer Nature remains neutral with regard to jurisdictional claims in published maps and institutional affiliations. 